Anyone who has worked at a public service desk in a library has probably had at least one encounter with a genealogy researcher avidly regaling them with some new fact they learned about their ancestors. Genealogy researchers bring a passion to their efforts that is unmatched, so it behooves libraries to have the best resources on hand. While a lot of the genealogy legwork is done online these days via Ancestry.com and FamilySearch.org, there is still a need for highquality print resources. At the time of the column's writing, many libraries were shut down due to the coronavirus pandemic, rendering print resources inaccessible. By the time this column appears, libraries will be again serving these passionate researchers with a range of the best print resources to go along with online tools. Author Katherine Pennavaria is Library Director at Thaddeus Stevens College of Technology in Lancaster, Pennsylvania. She is the author of Genealogy for Beginners (2020) and Genealogy: A Practical Guide for Librarians (2015) as well as numerous columns on genealogy in Kentucky Libraries. Katherine has done numerous national and state presentations related to genealogy; topics include genealogy record types, search strategies, and resources the beginning researcher needs to know about.-Editor

\section{Katherine Pennavaria}

Katherine Pennavaria is Library Director at Thaddeus Stevens College of Technology in Lancaster, Pennsylvania.

Correspondence concerning this column should be addressed to Mark Shores; e-mail: shoresml@miamioh.edu.

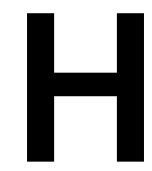
as there ever been a better time to work on genealogy? Just about everybody is spending most of their time at home during the pandemic-inspired shutdown, and family history research, which takes dedicated time and effort, is the perfect project. Unfortunately, most aspiring researchers have limited or even no access right now to library print collections, which potentially could contain just the right book to get them started or help them past a brick wall. This unprecedented situation, where potentially helpful publications sit untouched on library shelves, is not going to last. To prepare for the eventual return to some version of "normal," libraries across the country should consider purchasing the books listed here, in both print and e-book form if possible. All of them are produced by established publishers and have undergone an editing and fact-checking process that most web-original information is not subject to.

Sometimes, genealogy information and advice get out of date, such as reviews of software programs. But best research practices don't change so quickly, and advice about the most effective strategies and steps is likely to hold good for many years. Libraries that possess these volumes will see them circulate again and again as more and more people jump on the genealogy train. It has never been more popular to take 
up, or more important to get right: everyone, from beginners to advanced family history researchers, needs sound, tested advice.

Note: My own publication, Genealogy for Beginners (ISBN: 978-1538125489), was published in February 2020_it is a thorough exploration of the process, the resources, and best practices for a beginner.

\section{GENERAL GUIDES}

Croom, Emily Anne. Unpuzzling Your Past, 4th ed. Baltimore, MD: Genealogical Publishing Company, 2010 (ISBN: 9780806318547).

Genealogy research is never easy, but it can be made easier with books like this, which takes a complicated process and breaks it down into steps. Croom is an experienced genealogist, historian, and writer, and has produced several other books, including a workbook to accompany Unpuzzling Your Past, The Genealogist's Companion E Sourcebook, and The Sleuth Book for Genealogists.

Morgan, George C. How to Do Everything: Genealogy, 4th ed. New York: McGraw-Hill, 2015 (ISBN: 978-0071845922).

Morgan, one of the co-hosts of the popular "Genealogy Guys" podcast, lays it all out: how to do family history using the most current available records, accessing records archives offline, and using social media tools to discover and share. He also covers the important but sometimes overlooked task of placing newly discovered information into the correct historical context.

Smith, Drew. Organize Your Genealogy: Strategies and Solutions for Every Researcher. Cincinnati, OH: Family Tree Books, 2016 (ISBN: 978-1440345036).

Smith is the other half of the "Genealogy Guys" podcast. He addresses the vital issue of getting and staying organized as you pursue family history records and data. The undertaking is essentially a research project, so having a research plan, a file labeling strategy, and an organized workspace will lead to better outcomes. Smith emphasizes the need to determine goals and objectives for research, especially before making any physical fact-finding trip, and keeping track of correspondence. This book can help researchers at any level make the most of their time and effort. It includes checklists and worksheets to apply the book's advice.

Smolenyak, Megan. Who Do You Think You Are? The Essential Guide to Tracing Your Family History. New York: Penguin, 2014 (ISBN: 978-0143118916).

Smolenyak's career as a genealogist is many-layered. In this official companion guide to the popular series "Who Do You Think You Are?" (for which she served as chief genealogical consultant), she takes the reader on a breezy, entertaining trip through the highways and byways of family history research, especially the most useful records and how to find them. It is a warm and inviting place to start for the uninitiated, but even experienced researchers can learn some new tricks. Perfect for public library circulating collections.

Szucs, Loretto Dennis and Sandra Hargreaves Luebking. The Source: A Guidebook to American Genealogy, 3rd ed. Provo, UT: Ancestry Publishing, 2006 (ISBN: 978-1593312770).

Often referred to as the "genealogist's bible," The Source has been around for a while but has not lost its usefulness. The authors intended it as a handbook and guide for finding and using genealogy records, but it is also a tool for newbies and a good refresher for experienced researchers. The book consists of twenty chapters authored and signed by experts in the field, all with recommendations for further reading and illustrations. The Source is an essential buy for genealogy collections.

\section{FINDING RECORDS}

Colletta, John P. They Came in Ships: A Guide to Finding Your Immigrant Ancestor's Arrival Record, 3rd ed. Orem, UT: Ancestry, 2002 (ISBN: 978-1630264703).

Just about every American can trace part of his or her family history to someone who came to the US from elsewhere in the past three hundred years. This book is a useful overview of the documents relating to those arrivals from all over the world. Colletta provides not only the details of which records are useful in researching immigrant ancestors who arrived by ship, but also covers how the immigration process itself has evolved.

Eichholz, Alice (ed.) Red Book: American State, County and Town Sources, 3rd rev. ed. Provo, UT: Ancestry Publishing, 2004 (ISBN: 978-1593311667).

Organized by state, this book provides detailed information about county and town records sources along with maps and other illustrations. Of particular interest is the coverage of state and territorial censuses, which sometimes get overlooked by researchers who focus on the better organized decennial federal census. This one belongs on the reference shelf of any library with patrons pursuing genealogy.

Hendrickson, Nancy. Unofficial Guide to Ancestry.com: How to Find Your Family History on the \#1 Genealogy Website, 2nd ed. Cincinnati, OH: Family Tree Books, 2018 (ISBN: 9781440353260).

Every family history researcher in the US uses Ancestry-with millions of original records and a flexible search interface, it is the biggest and the best tool available. But getting the most out of what it contains is not easy. This book offers advice, complete with examples and illustrations, for how to use Ancestry's search template and "card catalog" effectively and how to interpret its unique "hint" system; it includes a section on Ancestry's DNA test. Researchers at all levels will find something useful in this volume. 


\section{THE ALERT COLLECTOR}

Kemp, Thomas Jay. International Vital Records Handbook, 7th ed. Baltimore, MD: Genealogical Publishing Co., 2017 (ISBN: 978-0806320618).

A standard reference resource for genealogy, the IVRH provides state-by-state and country-by-country forms for requesting birth, marriage, and death records (what genealogists call the "hatch, match, and dispatch" trio) along with lesser-used records such as passports and Social Security. Readers can scan the forms and print them. Even when forms have evolved or changed, the ones in this book are an excellent place to start, if only to get an address or office name. Libraries will want to keep the latest edition on the reference shelf.

\section{PRESERVING FAMILY PHOTOS AND PAPERS}

May-Levenick, Denise. How to Archive Family Photos: A Step-by-Step Guide to Organize and Share Your Photos Digitally. Cincinnati, OH: Family Tree Books, 2015 (ISBN: 9781440340963).

We've all got family photos stashed away-and what better legacy can we leave to future generations than to preserve those photos, both physically and digitally? Some lucky family historians have even inherited older photo collections, precious heirlooms that deserve to be shared with other family members. Denise May-Levenick has been offering her expertise for how best to preserve family photos for many years, first as part of her blog, "The Family Curator," and then with print publications such as this one. This book is a practical how-to for organizing digital photos, scanning and labeling prints, and then sharing the images with others.

\section{DOCUMENTING SOURCES}

Jones, Thomas W. Mastering Genealogical Documentation. Arlington, VA: National Genealogical Society, 2017 (ISBN: 9781935815242).

Documentation-laying out exactly where you accessed an original source and noting appropriate credit for information and images used-can seem like the "busy work" of research. Admittedly it is not the most engaging aspect of family history research, but it is vital to the quality of the information collected and shared. Documenting sources gives a researcher's work credibility because it allows someone else to verify data and information independently. Without documentation, the information might be true or might be false-there's no way to tell. Every researcher can and should learn to cite and describe sources with clarity, conciseness, completeness, and competence. The book contains exercises with answers to help researchers at all levels learn to do better documentation.

Mills, Elizabeth Shown. Evidence Explained: Citing History Sources from Artifacts to Cyberspace, 3rd ed. Rev. Baltimore,
MD: Genealogical Publishing Company, 2017 (ISBN: 9780806320403).

There is no bigger name in the world of genealogy documentation than Elizabeth Shown Mills. She is one of the field's superstars, having pioneered the practice and championed the importance of accurate documentation. Evidence Explained is the "bible" of documentation because it covers not just citing sources but analyzing them correctly. Mills, the longtime editor of the National Genealogical Society Quarterly and past president of both the American Society of Genealogists and the Board for Certification of Genealogists, makes abundantly clear the relative relationship between sources, information, evidence, and proof. Anyone wanting to share their findings publicly should delve into this book and master those distinctions. Mills has helped a generation of genealogists grow into real historians with her work on evidence and documentation. No library should be without the latest edition of this volume.

\section{ETHNIC HERITAGE RESEARCH}

Alzo, Lisa A. The Family Tree Polish, Czech and Slovak Genealogy Guide: How to Trace Your Family Tree in Eastern Europe. Cincinnati, OH: Family Tree Books, 2015 (ISBN: 9781440343278)

Millions of Americans can trace part of their ancestry back to Polish, Czech, or Slovak immigrants who were some of the latest arrivals in the myriad waves coming over from Europe. Because they arrived after the processing workflow included extensive documentation, finding the arrival records for these ancestors is usually easier than looking for arrivals prior to the mid-19th century. This guide takes the aspiring researcher through the process of identifying the town of origin for each Polish, Czech, or Slovak ancestor, provides vital and extremely helpful information about finding and translating non-English records, and even covers the shifting boundaries and complicated history of the parts of Europe they came from. Libraries in cities with populations descended from Polish, Czech, or Slovak immigrants will want to provide this excellent resource.

Beidler, James M. The Family Tree German Genealogy Guide: How to Trace Your Germanic Ancestry in Europe. Cincinnati, OH: Family Tree Books, 2014 (ISBN: 978-1440330650).

Millions of Americans have some German ancestry, but delineating those Germanic lines isn't easy because Germanspeaking people were among the earliest groups to settle America, and they continue to arrive well into the twentieth century. Beidler tackles the challenge effectively and includes research advice for finding German-speaking ancestors who lived in areas of Europe that are not in historic or modern Germany. He also offers help with learning the precise place in Europe that someone came from (almost always the place that person was born) and then explains how to access German records in that place. Especially useful is a section on 
deciphering German-language records, which sometimes use a peculiar script that few today can read without help. This volume is useful for researchers at all levels and especially appropriate in American locations with large populations descended from German settlers.

Burroughs, Tony. Black Roots: A Beginner's Guide to Tracing the African American Family Tree. New York: Fireside Books, 2001 (ISBN: 978-0684847047).

Though somewhat dated, Burroughs' book is still the standard for the unique challenge that is tracing the African American family tree. It's easy to get discouraged by the lack of records prior to the late nineteenth century, but Burroughs makes the task easier by highlighting the special problems facing researchers on this topic. He lays out sensible and effective strategies and illustrates the process with real case histories and covers the unique problems that the researcher will face. The book contains copious illustrations and examples plus worksheets and forms. Indispensable for aspiring researchers with African American ancestry.

Grenham, John. Tracing Your Irish Ancestors, 5th ed. Baltimore, MD: Genealogical Publishing Company, 2019 (ISBN: 9780806316178).

Crammed with detailed lists and specifics about record locations all over Ireland, this latest edition covers the newest available information about how to access records online and interpret DNA testing results. It is a tad dense and weighty, and as such might be intimidating for beginners, but for the American family history researcher who has identified his/her immigrant ancestors from the Emerald Isle and is ready to "cross the pond," this volume is a terrific guide to the tricky process of locating Irish records. Grenham's book includes source lists for thousands of towns all over Ireland, and for both Protestant and Catholic church records.

Holtz, Melanie. The Family Tree Italian Genealogy Guide: How to Trace Your Family Tree in Italy. Cincinnati, OH: Family Tree Books, 2017 (ISBN: 9781440349058).

Italian records are unusually well-documented by the Family History Library, and they are accessible in huge numbers at the FHL's site. This guide will help with every phase of Italian heritage research, from pinpointing the town in Italy someone came from to working with original-language records online at Ancestry and FamilySearch. There is significant practical advice, including a section on dealing with foundling records in Italy.

Roulston, William. Researching Scots-Irish Ancestors: The Essential Genealogical Guide to Early Modern Ulster, 1600 1800, 2nd ed. Belfast: Ulster Historical Foundation, 2018 (ISBN: 978-1909556652).

More targeted to a specific time period and Irish population than Grenham's Tracing Your Irish Ancestors, this volume drills down into the complex and fascinating research process for tracing Scots-Irish ancestry (which many Americans have, especially in the South). Ulster is basically the big chunk of Ireland that comprises the north-that is where the Scots-Irish people came to the US from (but not where they originated). Roulston includes information about finding Ulster church records-always a vital records source for European immigrants-as well as business and legal records. The appendices break down the sources available for every parish in the historic nine counties of Ulster between 1600 and 1800, and list more than 500 towns and villages. Anyone tackling their Scots-Irish ancestry will find this book invaluable.

\section{GENETIC GENEALOGY}

Bettinger, Blaine T. The Family Tree Guide to DNA Testing and Genetic Genealogy, 2nd ed. Cincinnati, OH: Family Tree Books, 2019 (ISBN: 978-1440300578).

Bettinger is one of the biggest names in genetic genealogy, and you can be sure patrons will come looking for his books. This one is a solid win-he takes the reader through what DNA tests provide, how they work, the pros and cons of the major testing companies, and how to get answers to genealogy questions using DNA data. He also covers the slippery subject of third-party sites like GEDmatch and the privacy laws that impact the use of DNA data. This book is routinely recommended by professional genealogists who work with genetic results, along with Bettinger and Wayne's workbook, Genetic Genealogy in Practice (see next entry).

Bettinger, Blaine T. and Debbie Parker Wayne. Genetic Genealogy in Practice. Arlington, VA: National Genealogical Society, 2016 (ISBN: 978-1935815228).

Think of this as a companion to Bettinger's Family Tree Guide to DNA Testing and Genetic Genealogy. It is a workbook with practice tests and answers, which begins by providing a conceptual grounding in the science of DNA testing. The authors then go methodically through the many complex aspects of genetic science and steer the learner toward genealogical conclusions that can be demonstrated with genetic evidence. Someone who just wants a simple interpretation of their own DNA testing results doesn't need this bookthe testing companies provide that with the test fee. But if that someone really wants to understand the field of genetic genealogy, this book is a must-read.

\section{SOCIAL/CULTURAL HISTORY}

Handlin, Oscar. The Uprooted: The Epic Story of the Great Migrations That Made the American People, 2nd ed. Philadelphia: University of Pennsylvania, 2002 (ISBN: 9780812217889).

This book is older than many of its potential readers-it won the 1952 Pulitzer Prize in history. But it is still a winner 


\section{THE ALERT COLLECTOR}

all these years later. Handlin brings the reader into the world of the millions who traveled from Europe to America in the late nineteenth and early twentieth centuries-a time after the arrival of the German, French, Spanish, English, Irish, and Scots-Irish settlers who colonized the country and pioneered the frontier. The later arrivals were, on average, poorer and more desperate than earlier arrivals. This book explores the nature of their social and economic realities and delves into the peculiar life that was the European peasant during the great migrations. Sometimes the story is disturbing, but it is always fascinating and eminently readable. This book is essential reading for anyone interested in the immigration phenomenon in the US and should be part of every circulating collection.

Wyman, Mark. Round-Trip to America: The Immigrants Return to Europe, 1880-1930. Ithaca, NY: Cornell University Press, 1993 (ISBN: 978-0801481123).

Wyman tells us the other side of the phenomenal success story that was (and is) immigration to American shores. We rightly celebrate our immigrant ancestors, but sometimes forget that we are descended from the ones who stayed. What about the ones who went back? Many times, then and now, immigrants have been encouraged to "go home" by nativist Americans who resented their arrival, and many do just that. This book is an academic study, a historical exploration of the myriad, complex social and economic realities that faced immigrants between 1880 and 1930. Wyman offers well-reasoned conclusions about why life in America simply didn't work out for millions of people who arrived, stayed a while, and then went back home.
Images of America series (Arcadia Publishing, Mount Pleasant, South Carolina)

In this series, Arcadia publishes books of pictorial history for American states, regions, cities, and even neighborhoods. The publisher employs local writers and historians to compile photographs that tell the history of a community and to write the captions and introductions. Every public library in America will find at least one or two relevant volumes for its area, and should consider also purchasing titles for surrounding counties and even states. You can search the Arcadia catalog at www.arcadiapublishing.com/series/ images-of-america-books.

\section{A FINAL SUGGESTION}

Luxenberg, Steve. Annie's Ghosts: A Journey into a Family Secret. New York: Hatchette, 2014 (ISBN: 978-1401310196).

The author was a working journalist when his mother died-six months later, he discovered a long-buried family secret: his mother had a sister who spent her adult life in a mental institution. Though not previously interested in pursuing his family history, Luxenberg decided to use his professional skills to bring the story of this newly discovered aunt to light. This book is not really about his aunt-it is the story of the author's journey to discover the truth about her life. While not a genealogy book per se, Steve Luxenberg's dogged pursuit of the records that unlocked a family mystery makes for a fascinating narrative that will appeal to anyone who researches their own family history. 